The American Journal of Political Science Law and Criminology (ISSN - 2693-0803)

VOLUME 04 ISSUE 01 Pages: 19-26

SJIF IMPACT FACTOR (2020: 5. 453) (2021: 5 • 952)

OCLC - 1176274523 METADATA IF - 7.659

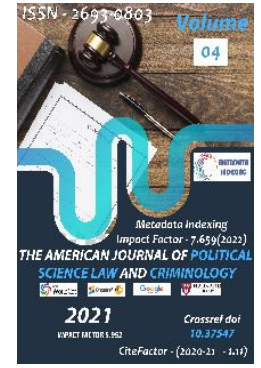

Journal Website: https://theamericanjou rnals.com/index.php/ta jpslc

Copyright: Original content from this work may be used under the terms of the creative commons attributes 4.0 licence.

Research Article

\title{
THE ROLE AND IMPORTANCE OF TRADE UNIONS AS AN INSTITUTION OF CIVIL SOCIETY IN UZBEKISTAN
}

\author{
Submission Date: January 09, 2022, Accepted Date: January 20, 2022, \\ Published Date: January 30, 2022 \\ Crossref doi: https://doi.org/10.37547/tajpslc/Volume04Issue01-04 \\ Avezov Umidjon Toshpulatovich \\ Independent researcher of the Tashkent State University of Law, Uzbekistan
}

\section{ABSTRACT}

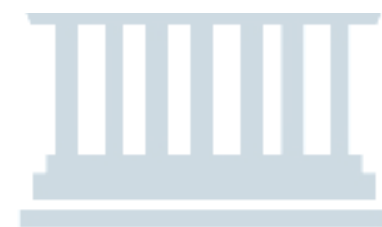

This article analyzes the concept of a trade union and its legal nature, the role and importance of trade unions as an institution of civil society in Uzbekistan, the functions and basic principles of trade union activity, the organizational and legal foundations of trade unions. The article also provides a constitutional and legal analysis of the concept of a trade union and its legal nature, an analysis of the functions and basic principles of trade union activity, a study of the stages of development of the legislative system of trade unions in Uzbekistan, organizational and legal issues of trade union activity, a study, an analysis of the legal nature of documents adopted by trade unions, comparatively - legal analysis of foreign experience in organizing trade union activities, determining priority areas for improving trade union activities, developing proposals and recommendations for improving the legislation governing this activity, and other issues were also analyzed.

\section{KEYWORDS}

Trade union, trade union activity, self-governing bodies of citizens; religious organizations; national and cultural centers; voluntary societies, civil society institutions, labor protection requirements. 
The American Journal of Political Science Law and Criminology (ISSN - 2693-0803)

VOLUME 04 ISSUE 01 Pages: 19-26

SJIF IMPACT FACTOR (2020: 5 - 453) (2021: 5. 952)

OCLC - 1176274523 METADATA IF - 7.659

Crossref dol gु' Google

\section{INTRODUCTION}

Civil society, along with the state and business, is the "third sector" of society. It includes civil society institutions and non-governmental organizations. The UN recognizes the importance of cooperation with civil society and promotes the ideas of civil society [1].

Although the state is not part of civil society, it creates the necessary conditions for its normal, orderly functioning. The state refrains from regulating the life of civil society, because the state, which considers itself legal, obeys only the law.

At the same time, there is no consensus on the concept of "civil society institutions". In the current legislation, there is no final rule explaining the essence of this term [2]. A number of scholars expressed their opinion on the content of civil society institutions. In particular, according to L. Yu. Grudtsina, the institutions of civil society are made up of its constituent elements (individuals) and their activities are primarily aimed at the realization and protection of their rights and freedoms by individuals, the solution of common tasks in all spheres of public life social groups that create relationships, secondly, can influence state institutions and are able to protect citizens from their unreasonable interference in public life. According to J. Shirinov, the institution of civil society is a structure of human society formed on the basis of common goals and voluntary participation of participants, the main activity of which is not focused on generating income (profit), independent of the state, politically independent and economically free [3].

Summarizing the above, it should be noted that civil society institutions are politically independent institutions that serve the development of civil society, which excludes excessive state interference in public life, sanctioned by the mechanism of effective public control over state power. Currently, the concept of civil society institutions is used in more than 50 current regulatory legal acts of the Republic of Uzbekistan. Of these, 20 codes and laws, 20 decrees and resolutions of the President of the Republic of Uzbekistan, 8 resolutions of the Cabinet of Ministers and 2 departmental and regulatory documents [4].

Civil society institutions - various voluntary associations, unions and public organizations, relatively independent of the state, self-governing, representing the rights, freedoms and legitimate interests of a person and citizen, realizing their needs.

In turn, the role and importance of civil society institutions in the life of our society is reflected in:

- represents the interests of various social groups of the population;

- is an important factor in strengthening democratic values in the minds of citizens, increasing their political and civic activity, expanding and deepening the scale of democratic reforms in the country;

- are the main means of public control over the activities of state and power structures;

- the use of their capabilities in understanding the national identity, political and legal culture and the national worldview of members of society, the implementation of the national idea and the ideology of national independence;

- are equal social partners of the state in the implementation of issues of public importance;

- A developed system of non-governmental nonprofit organizations determines and strengthens the harmony of interests in society [5]. 
The American Journal of Political Science Law and Criminology (ISSN - 2693-0803)

VOLUME 04 ISSUE 01 Pages: 19-26

SJIF IMPACT FACTOR (2020: 5 - 453) (2021: 5. 952)

OCLC - 1176274523 METADATA IF - 7.659

Public associations play an important role among civil society institutions. They make a worthy contribution to the ongoing reforms in our country, to the development of our country.

Civil society institutions operating in our country can be classified according to the following criteria [6]:

- Structures that meet the interests of the economic sphere: non-governmental organizations created and operating on the basis of private property; rental teams; joint-stock companies; financial funds and associations; production corporations, concerns and associations; business associations (chambers) and others;

- Structures representing interests in the social sphere: special organizations representing the family and its interests; educational institutions (schools, secondary specialized and higher educational institutions); public associations, nongovernmental organizations; self-governing bodies of citizens; independent media; religious organizations; national and cultural centers; voluntary societies; public opinion research institutes; structures that fairly resolve various social conflicts, etc.

- Institutions and structures representing interests in the political sphere: political parties; sociopolitical movements; presence of political opposition; human rights institutions, etc.

The specificity of trade unions determines their role and place in the system of civil society institutions.

According to the Russian scientist A.Mironov, trade unions cannot be excluded from the political life of society. Indeed, through the system of developing and discussing bills, trade unions participate in creating a legal framework for protecting the rights and interests of workers and influencing the socio-economic policy pursued by the authorities [7].

Trade unions in Uzbekistan are one of the largest and most popular public associations and represent social and economic interests.

At the same time, the law enshrines the right of civil society institutions to exercise public control. In particular, legislation on the activities of trade unions, self-government bodies and other institutions of civil society regulates the procedure for exercising public control.

In this regard, according to J.Shirinov, the Law of the Republic of Uzbekistan "On Trade Unions" adopted on December 6, 2019 increased the role of trade unions in protecting the socio-economic rights of citizens. It should be noted that a separate section of the law is devoted to the exercise of public control by trade unions. In order to exercise public control over the industry, trade unions were given the right to create special inspections [8].

As an institution of civil society, trade unions, as institutions of civil society in the social sphere, carry out activities aimed at realizing the socio-economic rights of citizens.

Civil society institutions in our country note the emergence of non-governmental non-profit organizations in the form of charitable foundations. After the introduction of Islam on the territory of modern Uzbekistan in the Middle Ages, philanthropy has been an integral part of people's lives for many centuries. In Uzbekistan and other countries of Central Asia, public associations and other public institutions have manifested themselves mainly in the form of selfgovernment bodies - mahallas. In 1924-1925, a number of public organizations emerged in Uzbekistan, such as 
The American Journal of Political Science Law and Criminology (ISSN - 2693-0803)

VOLUME 04 ISSUE 01 Pages: 19-26

SJIF IMPACT FACTOR (2020: 5 - 453) (2021: 5. 952)

OCLC - 1176274523 METADATA IF - 7.659

the Komsomol, trade unions, the Women's Committee, which were guided by their goals, ideas and ideology. The first stages of trade union activity in Uzbekistan can be recommended in connection with the desire of trade unions in the post-Soviet space in the late $80 \mathrm{~s}$ and early 90 s to become independent in all spheres of public life.

At that time, the unions were forced to obey and act in accordance with the decisions of the Center, even if they were contrary to the interests of local workers.

As soon as the Republic of Uzbekistan gained its independence, it declared to the international community that its ultimate goal was the formation of a free civil society and the rule of law. Therefore, in the conditions of civil society and the rule of law, conditions are created for the comprehensive development of the individual, the comprehensive protection of human rights and freedoms. In the process of achieving this goal, it is important to strengthen and enhance the structural institutions of civil society, in particular the role and place of public organizations in society. "If the state does not allow civil activity or create conditions for the activity of various non-governmental and public associations in identifying and solving such problems, building a civil society will remain problematic. Paying special attention to the role and importance of civil society institutions, President Mirziyoyev said at a joint meeting of the Oliy Majlis on the occasion of the inauguration of the President of the Republic of Uzbekistan: We believe that citizens self-government bodies - mahallas, as well as non-governmental organizations, free and impartial media - will play an active role. In implementing the important principle "from a strong state to a strong civil society", "we rely primarily on the strength and capabilities of these social institutions". That is why in countries with a developed civil society, public organizations operate in all spheres of public life [9].

Significant steps have been taken to form a civil society and provide all possible support to its institutions. In particular, in accordance with the Decree of the President of the Republic of Uzbekistan "On measures to promote the development of civil society institutions in Uzbekistan" (June 23, 2005), a very diverse civil society The creation and development of institutions is a very important task in building a democratic rule of law, an open civil society with a developed market economy in Uzbekistan [10].

The distinctive features of trade unions in Uzbekistan as institutions of civil society are reflected in the fact that trade unions use material resources only in the interests of society, trade unions exercise public control over state bodies and officials, and contribute to further strengthening the foundations of civil society in the country to represent the interests of employees.

It is known that the essence, content and purpose of any organizational structure are expressed in the functions and directions of its activities. In particular, the functions of trade unions are also reflected in their influence on society through the implementation of certain activities. In this regard, trade unions, which are one of the most massive forms of public organizations, also have a significant impact on the social development of society.

The above analysis of the functions performed by trade unions shows that today the activities of these institutions to protect the rights of workers in the labor sphere are carried out mainly through the following mechanisms: bilateral or multilateral agreements, collective conclusion of agreements and labor agreements, social partnership and others. 
The American Journal of Political Science Law and Criminology

(ISSN - 2693-0803)

VOLUME 04 ISSUE 01 Pages: 19-26

SJIF IMPACT FACTOR (2020: 5. 453) (2021: 5. 952)

OCLC - 1176274523 METADATA IF - 7.659

In accordance with the law, the functions of trade unions for labor protection include:

- participation in the investigation of accidents at work and occupational diseases;

- make proposals to the employer on the suspension of work in cases of danger to the life and health of employees, as well as on the elimination of violations of labor protection requirements;

- study of the state of labor protection, control over the fulfillment of the obligations of employers on labor protection, provided for by collective agreements and contracts;

- participation in the examination of the safety of working conditions at designed, constructed, reconstructed and operated production facilities, as well as in the examination of the safety of designed and operated means of production;

- participate as independent experts in the work of commissions for testing and adjustment of production facilities and means of production;

- participation in meetings of the medical and labor expert commission;

- participation in the development of draft regulations and technical regulations in the field of technical regulation and labor protection;

- apply to the relevant authorities with a demand to bring to justice those responsible for violating labor protection requirements, concealing the facts of accidents at work;

- the right to compensation for harm caused to the employee by disability or other damage to his health in connection with the performance of his duties, and in other cases when the employee's rights to health and work are violated, the right to claim in defense of the employee's rights.

An analysis of Article 30 of the Law of the Republic of Uzbekistan "On Trade Unions" shows that trade unions also perform economic functions. The employer promptly, at least two months in advance, informs the relevant trade union or the trade union representing the interests of employees about the possibility of mass dismissal of employees and consults on mitigating the consequences of dismissal. Trade unions and their associations have the right to submit proposals to local self-government bodies to suspend the employer's decision on the mass dismissal of workers for up to six months. An analysis of these norms shows that trade unions have the opportunity to receive up-to-date information about the economic problems of the employer, overcome the economic crisis and make proposals for improving management. In order to exercise these rights, trade unions have the right to receive free information about the socioeconomic rights and interests of employees from state bodies, their officials and employers in order to carry out their statutory activities in accordance with the law. Thus, today in the process of deploying democratic reforms, the formation of civil society, an important factor is the role of trade unions in the economic function. Because trade unions, through their economic function, effectively influence the activities of the employer and the enterprise, overcoming the economic crisis and making proposals for improving management.

From the experience of foreign countries, we see that trade unions strengthen their political functions through the formation of political parties. For example, in 1900 the British trade unions formed their own political party, the Committee of Workers' Representatives, and in 1906, the Labor Party. Trade unions directly finance this party. Most workers in Sweden The Swedish Trade Union Confederation provides the political leadership of the Swedish Social Democratic Party [11]. 
The American Journal of Political Science Law and Criminology (ISSN - 2693-0803)

VOLUME 04 ISSUE 01 Pages: 19-26

SJIF IMPACT FACTOR (2020: 5 - 453) (2021: 5. 952)

OCLC - 1176274523 METADATA IF - 7.659

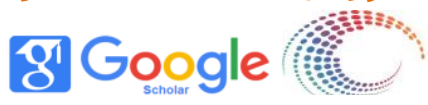

metapata

5) WorldCat אి MENDELEY

Publisher: The USA Journals

The auxiliary functions of the trade unions include: the function of the socialization of labor; expert advisory function; information and analytical function; teaching function; communicative function; economic functions, etc.

In the period of transition to a market economy, changes in the course of reforms, innovative innovations, the importance of the expert advisory function of trade unions increases. Trade unions play an important role in improving the legal literacy of workers by studying regulations, participating in the development of technical and organizational projects, economic programs and shaping the legal outlook of their members on labor rights, pensions, social insurance and other social and legal issues, performance of tasks.

It should be noted that the role of social relations in the implementation of equal interactions of employees in the context of human and professional requirements is of particular importance. A special place in this communication is given to the communicative function performed by trade unions. Consequently, the consolidation of workers is achieved through various meetings, conferences, conferences organized by trade unions on socio-political, legal, cultural issues.

Trade unions also perform their economic functions as separate legal entities. In the process of privatization, the form of ownership of many social facilities has changed, but they also include a number of independently funded structures in the field of cultural, educational, medical, preventive, physical culture and sports. At the same time, today trade unions carry out commercial activities through paid services, renting buildings and structures, and opening private enterprises.
In our opinion, in addition to these principles, the legislation provides for the observance of financial discipline by trade union bodies and trade unions, collegiality in the work of trade unions and trade union bodies and personal responsibility of elected officials, solidarity, mutual assistance and responsibility. trade unions should also be reflected in legislation.

The principle of financial discipline of trade union bodies and trade union organizations ensures the unity of trade union financial policy, and this principle is important for understanding the economical, efficient and targeted use of trade union funds.

In the work of trade union organizations and trade union bodies, the principle of collegiality and personal responsibility of employees elected to trade union bodies establishes a balance between the rights and obligations of members of the collegial trade union body.

The principle of solidarity, mutual assistance and responsibility of trade unions is important in that it determines that the provisions of the charter of the trade union have direct effect and apply to all members of the trade union, trade union organizations and their elected bodies.

In conclusion, it should be noted that the essence, content and purpose of trade unions, their specific features are expressed in the basic principles that determine its functions and activities. The functions of trade unions are reflected in their influence on the life of the state and society through the protection and promotion of the rights and interests of their members. It is obvious that the improvement of the legal base of the functions and principles of trade unions, which are one of the main forms of public associations in the regulation of public relations, serves to increase their place and role in civil society. 
The American Journal of Political Science Law and Criminology (ISSN - 2693-0803)

VOLUME 04 ISSUE 01 Pages: 19-26

SJIF IMPACT FACTOR (2020: 5 - 453) (2021: 5. 952)

OCLC - 1176274523 METADATA IF - 7.659

Summarizing approaches to the essence of a trade union as a public association and a non-governmental non-profit organization created on the initiative of citizens, we can draw the following conclusions:

A trade union is a public association of workers who voluntarily unite to protect the rights and socioeconomic interests of workers in labor relations, to maintain and improve working conditions.

Based on the analysis of the legal nature of trade unions, they have the following features: the legal status of trade unions (unlike other public associations) is enshrined in the Constitution of the Republic of Uzbekistan; the legal status, rights and obligations of trade unions are also regulated by the legislation on related non-governmental non-profit organizations and public organizations; voluntary composition of citizens in order to express their rights (social, economic, cultural, educational, political) related to the general professional interests of their activities or type of education; create and act directly in labor collectives in accordance with the current legislation, unlike other public organizations; is an institution of civil society representing political interests in terms of representing the socio-political interests of citizens in the field of ensuring labor rights; unlike other types of public organizations, a trade union can only be created by natural persons and cannot be created in any other way.

In Uzbekistan, trade unions are guided by the Constitution, a special law and the Labor Code in accordance with the Social Partnership Model. The activities of trade unions in the Republic of Uzbekistan are coordinated by the Federation of Trade Unions of the Republic of Uzbekistan, created for the joint implementation and protection of the rights and interests of its members.
The functions of industrial injuries include the following: the function of labor protection; representative function; cultural and educational function; social function; economic function; political function; control function.

Currently, the priority and urgent issues of improving the activities of trade unions in the country are: further simplification of the procedure for state registration of trade unions, establishing a constructive dialogue between employers and trade unions, introducing modern mechanisms of trade union activity. trade union activities. Improving the legal framework of public control, improving the functions of trade unions in conditions of social partnership, implementing international agreements on labor relations in national legislation and developing trade union legislation on gender equality, youth and social and labor issues, improving the legal framework for participation in the procedure.

\section{REFERENCES}

1. https://www.un.org/en/sections/resourcesdifferent-audiences/civil-society/index.html.

2. Yakubov Sh. Legal mechanisms of interaction between the state and civil society institutions / Monograph. - T .: “UROK PRESS”, 2018. - P. 16-17.

3. Shirinov J. Legal basis for organizing the activities of non-governmental non-profit organizations in Uzbekistan as an institution of civil society// doc. diss... - Tashkent: TSUL, 2021. - P. 23.

4. Shirinov J. The concept and structure of civil society institutions // Democratization and human rights. -T., - 2018. - №. 1. - P. 24-28.

5. Odilkoriev Kh. The constitution and the dream of a harmoniously developed generation. -T .: "Teacher", 2012. - P. 184-185.

6. Akhmedshaeva M., Ruzinazarov Sh., Najimov M.K., Sattarova G., Saidullaev Sh.A., Tukhtaboev 
The American Journal of Political Science Law and Criminology

(ISSN - 2693-0803)

VOLUME 04 ISSUE 01 Pages: 19-26

SJIF IMPACT FACTOR (2020: 5. 453) (2021: 5 • 952)

OCLC - 1176274523 METADATA IF - 7.659

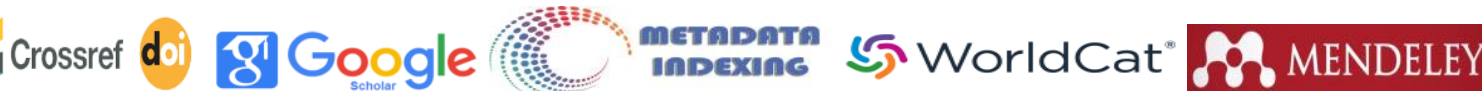

S.N. Institutions of social partnership and public control in Uzbekistan: theory and practice. Monograph. - Tashkent: TSUL, 2016. - P. 160.

7. Mironov A., The collective agreement in the new legal framework // Profodaozy. 2003. No. 1. - P. 1618.

8. Shirinov J. Legal basis for organizing the activities of non-governmental non-profit organizations in Uzbekistan as an institution of civil society// doc. diss... - Tashkent: TSUL, 2021. - P. 59.

9. Mirziyoev Sh.M. Speech at a joint meeting of the chambers of the Oliy Majlis, dedicated to the inauguration of the President of the Republic of Uzbekistan.

10. Decree of the President of the Republic of Uzbekistan "On measures to promote the development of civil society institutions in Uzbekistan" dated June 23, 2005 // Bulletin of the chambers of the Oliy Majlis of the Republic of Uzbekistan. 2005. №. 6.

11. http://files.school-

collection.edu.ru/dlrstore/f32e1cd3-7f4a-36d8-

50beo 6363 bdd823a/1010983A.htm. 